\title{
The power and limits of expertise: Swiss-Swedish linking of vehicle emission standards in the 1970s and 1980s
}

\author{
Mattias Näsman ${ }^{1 \star}$ (D) and Sabine Pitteloud ${ }^{2 \dagger}$ (D) \\ ${ }^{1}$ Umeå University, Unit of Economic History, Umeå, 907 36, Sweden and ${ }^{2}$ Harvard Business School, General Management Unit, \\ Boston, MA 02163, USA \\ ^Corresponding author: Mattias Näsman, Email: mattias.nasman@umu.se
}

\begin{abstract}
Recent decades have witnessed increased public concern about vehicle emissions and growing frustration with political inaction and business preferences for the status quo. This article provides historical perspective on such regulatory dynamics by analyzing the Swiss and the Swedish cases of vehicle emission governance in the1970s-1980s. Relying on archival documents detailing the policy process in both countries as well as on international regulatory arenas, the analysis focuses on political solutions for reducing the toxicity of vehicle emissions. It uncovers the influence of national as well as international business groups and the existence of the tension between various national ministries, arising from conflicting environmental and trade-related goals. Is also highlights the importance of different institutional settings in creating the expertise to explain the political outcomes. While the Swiss corporatist system gave a great deal of power to a variety of interest groups at each stage of the political process, the Swedish government invested significant resources in the creation of independent expertise and enjoyed a relative autonomy, despite the importance of the Swedish car industry. The analysis also assesses the importance of the Swiss-Swedish collaboration in overcoming certain obstacles and their contribution to the implementation of stricter regulations in Europe that ultimately occurred at the margins of the European Economic Community.
\end{abstract}

Keywords: business power; car industry; vehicle emissions; expertise; environmental standards

\section{Introduction}

In May 1981, the association of car users and retailers in Switzerland published a pamphlet entitled "Turning Away from Europe" that deplored the fact that Switzerland chose to introduce standards that were more stringent than the norms in the European Economic Community (EEC). ${ }^{1}$ Moreover, the pamphlet criticized the "uncertain alliance" that the Swiss authorities were developing with Sweden to implement common certification procedures for new vehicles. This historical anecdote is representative of important trends characterizing the regulation of passenger car emissions in Western Europe. Firstly, the EEC was not at the forefront in reducing the toxicity of vehicle emissions in Europe. Secondly, some countries chose to develop bilateral technical cooperation, thereby contributing to standard harmonization at the margins of the EEC. Thirdly, their attempts faced opposition, particularly from business interests but also from some of the EEC member states.

This article aims at shedding light on such regulation dynamics by focusing on two countries that were forerunners in implementing stringent emission regulations in Europe, namely Sweden and Switzerland. The analysis adopts a comparative and transnational perspective in analyzing (1) how expertise on the technical options to reduce the toxicity of vehicle emissions was produced in Sweden and in Switzerland, respectively, and (2) how these two countries contributed to knowledge circulation and the

\footnotetext{
${ }^{\dagger}$ The authors declare that they have no conflict of interest.

${ }^{1}$ Christoph A. Bürgi, Abkehr von Europa. Auto vernüftig, die Informations und Dokumentationsstelle der Schweizer Automobilwirtschaft, 18.05.1981.

(c) The Author(s), 2022. Published by Cambridge University Press on behalf of V.K. Aggarwal. This is an Open Access article, distributed under the terms of the Creative Commons Attribution licence (http://creativecommons.org/licenses/by/4.0/), which permits unrestricted re-use, distribution and reproduction, provided the original article is properly cited.
} 
implementation of stricter regulation in Europe. The creation of technical expertise is viewed as resulting from power relations embedded in specific institutional settings at the national and international levels. Such an approach allows us to highlight concretely how business interests participated in norms creation and to assess, in a dialectical perspective, to what extent governments were able to develop a relative autonomy that enabled them to pursue environmental goals for the sake of public interests.

This article contributes to the history on vehicle emissions regulation in Western Europe, which has been particularly focused on the development within the EEC/EU ${ }^{2}$ and has almost completely overlooked regulatory and technical developments outside the Common Market. ${ }^{3}$ Such oversight is particularly regrettable because more stringent standards were primarily promoted and developed outside the EEC from the 1970s onward, substantiating the calls to explore alternative types of European integration through the lens of technology, that is by employing the concept of "linking." Moreover, the existing scholarship, developed mainly outside the history field, has not paid much attention to the role of expertise and the complexities of harmonizing technical standards, focusing instead on intergovernmental bargaining and competition. ${ }^{5}$ When organized business is mentioned, the preferences of the car industry are mainly deduced from public sources such as official statements and annual reports. ${ }^{6}$ A few historical studies have proven useful in showing that carmakers' influence was not limited to their ability to lobby politicians, but that their technical expertise mattered greatly in defining the regulatory options as well as in implementing the norms. ${ }^{7}$

This article therefore draws on those pioneering historical studies and complements them by looking beyond EEC countries and putting the creation of expertise at the center of the analysis. This article relies on a wide variety of historical sources from governments and business associations' archives. These myriad sources, collected in Switzerland and Sweden, allow for triangulation by confronting the perspectives of business representatives and civil servants, but also for cross-country comparisons by analyzing the creation of expertise in two different institutional settings. Furthermore, correspondence and minutes related to international meetings provides important insights about transnational knowledge circulation.

The article is structured as follows. "Standards, Expertise, and Power Relations" discusses the role of technological standards in Western European integration and the importance of business and techno-scientific experts in environmental policy making. "Prehistory" provides the political and economic context in which vehicle emission standards were developed during the postwar period. "Air Pollution on the Swedish and Swiss Political Agenda" explains how emission regulations arrived on the political agenda in Switzerland and Sweden and analyzes their different institutional approaches to achieving emission reductions. "Between Cooperation and Obstruction" focuses on the political struggles that arose from the mid-1970s and the relative power of organized business in both countries. "Engagement with Europe and the Oil Issues" describes the failed attempts by Switzerland and Sweden to find multilateral solutions. "The inauguration of a Swiss-Swedish approach to vehicle emissions" analyzes the rationale behind Swiss-Swedish cooperation and the way knowledge circulation helped both countries to move forward with their regulatory agenda. "The Stockholm Group" shed lights on the creation of the Stockholm group and its role in ultimately introducing unleaded gasoline in Europe, a necessary condition to fulfill stringent emissions limits. The last section concludes.

\section{Standards, expertise, and power relations}

Standards are commonplace in modern industrial economies, but standards for the performance of vehicles in terms of safety, emissions, and noise differ from industrial standards in that they are

\footnotetext{
${ }^{2}$ Moguen-Toursel (2003, 2011), Vogel (1995, 2012), Wurzel (2002), Arp (1995), Boehmer-Christiansen and Weidner (1995), Klebaner (2018), Warlouzet (2020). See also Ramírez-Pérez (2009, 2010, 2016).

${ }^{3}$ Ueli Haefeli (1999) provided general accounts of the evolution of the Swiss regulation.

${ }^{4}$ See, e.g., the seminal article by Misa and Schot (2005).

${ }^{5}$ Moguen-Toursel (2003, 2010, 2011); Ramírez-Pérez (2009, 2010, 2016); Vogel (1995, 2012); Wurzel (2002); Arp (1995); Boehmer-Christiansen and Weidner (1995); Klebaner (2018); Warlouzet (2020).

${ }^{6}$ Wurzel (2002); Haefeli (1999).

${ }^{7}$ Moguen-Toursel (2003); Klebaner (2018); Klebaner and Ramirez Perez (2019).
} 
enacted through legislation. Setting regulatory performance standards is a way for policy makers to achieve social goals for dealing with technological risks. ${ }^{8}$ In the case of vehicle emission standards, the social goals pertain to limiting health risks by controlling air pollution levels. The standards prescribe maximum emission limits for carmakers to meet in standardized laboratory tests. Up until the 1990s, the pollutants of main regulatory interests, owing to their harmful impacts on human health, have been hydrocarbons $(\mathrm{HC})$, carbon monoxide $(\mathrm{CO})$, and oxides of nitrogen $\left(\mathrm{NO}_{\mathrm{x}}\right)^{9}{ }^{9}$

Vehicle emission standards have been a topic of major conflict since the 1960s, when the United States and Western European countries implemented the first mandatory regulations. Emission standards have pitted national governments against the car industry, as well as against each other. ${ }^{10}$ Within this conflictual framework, the questions of how relevant information and technical expertise are constructed, and of who is perceived as a legitimate expert are crucial. Power and knowledge are indeed strongly intertwined, which implies, in a Foucaldian sense, that experts produce discourses that are sanctioned as true and that legitimate certain courses of action. ${ }^{11}$ In the case of the EEC, Klebaner and Ramirez Perez indeed show the importance of analyzing what type of information the Commission processed to elaborate the vehicle emissions legal frameworks and how the interpretation of this information was subject to constant negotiation between the different stakeholders. ${ }^{12}$ As they put it, "beyond the law stricto sensu, stakeholders (Commission, Member states, corporations, etc.) debated on its meaning: market distortions, international competitiveness, protectionism" and the building of common understanding was therefore at the center of the process. ${ }^{13}$ Indeed, the "standards" appear as a legal and technical nexus, for which the creation and diffusion of technical expertise, that is the determination of what is technically possible and enforceable in law, is subject to dynamic power relations.

Regarding the process of interpretation and bargaining surrounding emission standards enforcement, business interests mattered in several ways. Firstly, the car industry enjoyed a significant structural power in many European countries, thanks to its positive effects on trade balance and jobs creation, especially during the postwar period when cars became a mass consumption good. ${ }^{14}$ Moreover, standards also affected suppliers and subcontractors, as well as other related business activities such as retail and energy supply. Secondly, business interests exercised instrumental power through their lobbying activities. Some authors indeed refer to pamphlets addressed to the legislators by the car industry or its business interest associations such as the Committee of Common Market Automobile Constructors (CCMC), whose membership consisted of chairmen and CEOs of the largest car companies in the EEC. ${ }^{15}$ More generally, the literature has acknowledged the strategical use of technical standards to protect the Common Market against US and, later on, Japanese competition, as well as European governments' inclination to promote standards aligned with the interest of their national carmakers, which were determined by each firm's individual positioning in international competition and market segments. ${ }^{16}$ Structural and instrumental power should therefore not be considered as antithetical, but as two coexisting and often self-reinforcing phenomena. ${ }^{17}$ Moreover, some intermediary forms of "soft" power are relevant, such as the power to persuade and to appeal to shared interests and values. ${ }^{18}$ Indeed, business, by the creation of information and expertise, might be able to build common cause with the regulators and therefore be perceived as legitimate political actors.

\footnotetext{
${ }^{8}$ Vinsel (2015).

${ }^{9}$ In addition, carcinogenic particulate (PM) emissions became an issue of regulatory interest in the 1980s in relation to the breakthrough of the diesel technology. See Neumaier (2014).

${ }^{10}$ For the United States see, e.g., McCarthy (2007); Krier and Ursin (1977). For Western Europe, see Wurzel (2002); Boehmer-Christiansen and Weidner (1995).

${ }^{11}$ Foucault $(1980,133)$.

${ }^{12}$ Klebaner and Ramírez-Pérez (2019).

${ }^{13}$ Ibid., 443.

${ }^{14}$ Mattioli et al. (2020, 4) and Wilkins (1978).

${ }^{15}$ Klebaner (2018) and Moguen-Toursel (2011). Swedish Volvo was also part of CCMC through its ownership of the Dutch truck maker DAF. See Ramírez-Pérez (2009).

${ }^{16}$ Ramírez-Pérez (2009, 2010, 2016); Moguen-Toursel (2003, 2010, 2011); Klebaner (2018); Ballor (2021).

${ }^{17}$ Fuchs (2007) and Culpepper (2015).

${ }^{18}$ Nye (2004).
} 
While documenting business power is important, understanding the other side of the coin, that is the relative autonomy of the state, is also crucial. The organization of business-government relations and the balance of power between them were highly dependent on existing institutions as well as informal political procedures. ${ }^{19}$ The literature on corporatism and on the varieties of capitalism provides a general account of the organization of business-government relations. ${ }^{20}$ While it mainly focuses on the development of labor and economic policies in different countries, vehicle emission standards were at the intersection of economic, energy, health, and environmental policy and, consequently, subject to complex forms of interest representations and of institutional habitus between different ministries. In particular, the development of "external expertise" constituted an additional variable to the usual business-government relations and provided a certain leeway to politicians and civil servants. Moreover, international dynamics, including coalitions of business interests as well as the development of an international expert community, also defined the relative autonomy of states. Focusing on the creation of expertise therefore allows us to shed light on these complex processes of business influence and government autonomy at the national and international level.

This multilevel focus on power relations around technical expertise is also important to contribute to the literature on the European integration of environmental standards. In their seminal article, Thomas Misa and Johan Schot argued that historians should study European integration, not primarily as a political process, but as an "emergent outcome of a set of practices that involve linking and delinking of infrastructures, and the circulation and appropriation of knowledge and artifacts." ${ }^{21}$ By looking at the historical linking (and delinking) of infrastructures, such as railroads, highways, energy systems, and knowledge systems, historians have made visible the "hidden dimension" of European integration. $^{22}$ While the literature has not discussed regulatory standards in a similar way, the creation of international vehicle emission standards builds on similar hidden processes of knowledge circulation. $^{23}$ This article therefore investigates how knowledge circulation fostered European implementation of stringent vehicle emission standards, in the face of strong opposition from the car industry and EEC laggard countries.

\section{Prehistory: governing vehicle emissions in Europe}

In Western Europe, the governance of motor vehicle air pollution covered multiple levels of jurisdiction, stretching from the local to a national and international scale during the 1950s and early 1960s. Cities were responsible for enforcing local or national rules on noise and smoke control. National government administrations, professional organizations, research departments, and business groups conducted research regarding the share of motor vehicle exhaust in air pollution, the toxicity of pollutants, and methods and technologies for controlling emissions. ${ }^{24}$ Early on, experts, policy makers, and business actors stressed that the problems associated with motor vehicle air pollution had a transnational and international character. Firstly, road traffic as well as the trade in passenger cars between European countries was already intensive during the 1950s. This meant that cars polluted across borders and that governments had to regulate products produced abroad. Secondly, the car industry's business model relied on large-scale production for car parts and equipment, which meant that similar emission control requirements across countries were preferable. ${ }^{25}$

Geneva was the place where European countries and the car industry negotiated emission standards from the 1960s up until the early 1980s. Under the auspices of the United Nations Economic Commission for Europe (UNECE), the Working Party for the Construction of Vehicles (WP 29)

\footnotetext{
${ }^{19}$ Streeck and Schmitter (1999), 31.

${ }^{20}$ Hall and Soskice (2001).

${ }^{21}$ Misa and Schot (2005).

${ }^{22}$ See, e.g., Schipper (2008); Högselius (2013); Kaiser and Schot (2014); Högselius et al. (2016).

${ }^{23}$ See Näsman $(2021,31-32)$, for a discussion.

${ }^{24}$ See, e.g., Lemaigre (1966); Berg (1985); and Näsman (2021, ch. 5).

${ }^{25}$ On the economic and political challenges of disharmonious regulations in international trade, see Esty and Geradin (1997, 270).
} 
had, since its formation in 1952, worked to develop European standards for vehicle safety regulations. WP 29's membership included Western European countries while the United States and Japan had observatory roles. Governments' delegations, made up of ministry experts, had voting rights in WP 29, while peak-level associations such as the international car industry federation, BPICA (Bureau Permanent Internationale des Constructeurs d'Automobile), held a consultative position. Scholars have described WP 29 as a "mid-way between national standards negotiated in a bilateral basis between nation-states and attempts by multinational corporations to universalise their own standards," ${ }^{26}$ but also as a forum for circulating knowledge and solving issues related to the negative externalities of motoring, such as accidents and emissions. ${ }^{27}$ WP 29 discussed emission control for the first time in 1959, but it was not until after 1964 that Germany and France presented the first national proposals for vehicle emissions regulation. ${ }^{28}$ As a response, the BPICA proposed that the WP 29 form an expert rapporteur group to develop an international testing standard to facilitate harmonized regulation. WP 29 thus formed the Group of Rapporteurs on Air Pollution in March 1966, where French, West German, and Swedish experts developed a European testing standard (driving cycle), which WP 29 approved in March 1967. ${ }^{29}$ Under West Germany's threat of implementing unilateral norms, EEC states ultimately also agreed in 1970 on the first vehicle emission standards for CO and HC known as UNECE Regulation 15 and adopted it in a Community directive (70/220/EEC). ${ }^{30}$

During the same period, the United States was taking significant steps to reduce vehicle emissions, forcing carmakers to develop entirely new technological solutions, with the three-way catalytic converter being the breakthrough to achieve the intended goals (90 percent emission reductions). ${ }^{31}$ The stringency of European vehicle emissions regulations lagged significantly behind US regulations up until the 1990s. ${ }^{32}$ WP 29 amended Regulation 15 four times, by tightening the limits for CO and $\mathrm{HC}$ in 1974, introducing $\mathrm{NO}_{\mathrm{x}}$ limits in 1977, lowering the limits for $\mathrm{CO}, \mathrm{HC}$, and $\mathrm{NO}_{\mathrm{x}}$ in 1979 and later in 1980. Implementation of UNECE regulations was voluntary while any country applying Regulation 15 had the right to vote (or block) new amendments, leading to the view that the UNECE framework meant little more than lowest-common-denominator solutions. ${ }^{33}$ The EEC implemented the WP 29 amendments as optional harmonization directives. Progress in limiting the toxic content of passenger cars in Europe was therefore continuous yet slow during the 1970s, which frustrated countries and activists advocating for policies that were more stringent. Moreover, in relation to the second oil price shock of 1979/80, major conflicts between progressive, moderate, and laggard countries arose, owing to technical tradeoffs in controlling all pollutants and reducing fuel consumption at the same time. Governments within WP 29 did not manage to overcome these conflicts in goals, leading to the transfer of vehicle emission standards-setting from the UNECE framework to the EEC and toward non-EEC countries such as Sweden and Switzerland. ${ }^{34}$

\section{Air pollution on the Swedish and Swiss political agenda and early steps of expertise creation}

The difference in institutional settings, as well as the role business interest played in them, are important to explain the regulatory paths experienced by Sweden and Switzerland. In comparative political

\footnotetext{
${ }^{26}$ Ramírez-Pérez (2010, 188).

${ }^{27}$ Krebs (2012), Näsman (2021).

${ }^{28}$ Swedish National Archives [henceforth SNA], Kommunikationsdepartementets arkiv, internationella sekretariatet [henceforth KAIS], dossier F2, box 82, "Report of the Working Party on Its Fifth Session," 6-7.

${ }^{29}$ SNA, KAIS, dossier F2, box 83, "Report of the Working Party on Its Twenty-First Session," 24; idem, box 91, "Report of the Group of Rapporteurs on Air Pollution (GRPA) on Its Second Session"; idem, box 84, "Report of the Working Party on Its Twenty-Third Session," 20.

${ }^{30}$ Berg (1985, 23-24).

${ }^{31}$ Swedish Volvo was the first company to develop three-way catalytic converter systems for the American market and was therefore also the first company in the world to demonstrate such radical emission reduction. See Bergquist and Näsman (2021); Gerard and Lave (2005).

${ }^{32}$ Which is commonly noted in the literature. See, e.g., Vogel (2012) and Walsh (2011).

${ }^{33} \operatorname{Arp}$ (1995, 1-2); Boehmer-Christiansen and Weidner (1995, 14-15); Wurzel (2002), 97.

${ }^{34}$ Näsman (2021, chs. 10-12).
} 
economy and the varieties of capitalism literature, these two countries are usually described as (neo) corporatist or coordinated market economies to emphasize the importance of tripartite bargaining between labor unions, business interest associations, and the state in determining labor and economic regulation. ${ }^{35}$ While the creation of technical standards might be viewed as a type of economic policy, the involvement of environmental agencies and the use of scientists led to different policy negotiation patterns. The Swedish air pollution governance was notably centralized and offered few possibilities for nongovernmental interest groups-except the affected industry-to influence standard setting. ${ }^{36}$ Moreover, the Swedish authorities invested substantial resources to create independent expertise that could challenge the industry's view and ensure compliance. In contrast, and despite the absence of a national car industry, Switzerland's policy making was highly exposed to interest group representation. ${ }^{37}$ While the use of direct democracy by activists was important to generate a public debate and to set the regulatory process in motion, the political bargaining that followed was in line with wellestablished corporatist procedures. Indeed, various interest groups-mainly environmental NGOs and economic interests related to the vehicle and oil industries-could express their views during hearings and consultation rounds. Moreover, the newly established (1971) Swiss Federal Office for the Environment had to confront the Division of Commerce, whose close ties with the major business interest organization are well documented in the literature on Swiss capitalism and whose main goal was to promote free trade above any other consideration. ${ }^{38}$ Therefore, as we shall see, while Switzerland and Sweden shared common institutional features and environment-friendly goals on the surface, the role that business interests played in the creation of expertise, and consequently, the relative autonomy of policy makers, differed substantially.

Discussions related to the potential regulation of air pollution began in earnest in the Swedish and Swiss parliaments at the beginning of the 1960s. While water pollution had been the topic of political discussions previously, both countries initiated research, mapping, and monitoring efforts aimed at reducing air pollution from various sources in 1962-63. ${ }^{39}$ The Swiss government established the Federal Commission on Air Quality in 1961, whose mandate was to report on the importance and possibilities of tackling air pollution. Its members were primarily scientific experts, while "ad-hoc experts," mainly from the chemical industry, sometimes joined the meetings. At first the work of the commission targeted mainly stationary sources because industry and heating were responsible for the largest share of polluting emissions. ${ }^{40}$ Similarly, in 1963, the Swedish government formed a commission to propose regulations for controlling emissions and noise from stationary sources. ${ }^{41}$ Sweden started to tackle motor vehicle air pollution in 1965 with the creation of the Expert Group on Exhaust Emission Control (henceforth Expert Group) that aimed to propose regulations for vehicle exhaust emissions. It was composed of five experts from Swedish ministries and agencies and one representative from each of the Swedish carmakers Volvo and Saab-Scania, which, if the companies' total automotive operations were included, were some the largest private employers in Sweden in $1978 .{ }^{42}$

In addition to documenting emission issues, the Swedish and Swiss authorities also needed to set up bodies that could test the compliance of new vehicles and help enforce the norms. The Swedish government set up the Studsvik exhaust emissions laboratory-housed in the state-owned Swedish Nuclear Company's facilities-tasked with surveying vehicle emissions and testing emissions control technology. ${ }^{43}$ In Switzerland, similar tasks were delegated to the Swiss Federal Laboratories for

\footnotetext{
${ }^{35}$ Lindvall and Rothstein (2006); Katzenstein (1985, 30). Mach and Trampusch $(2011,11)$.

${ }^{36}$ See Lundqvist (1980) and Bergquist $(2007,35-47)$ for stationary source pollution and Näsman (2021) for motor vehicle air pollution.

${ }^{37}$ For a general account, see Eichenberger and Mach (2011)

${ }^{38}$ Drilewanger et al. (2004)

${ }^{39}$ Bergquist (2007, 35-36); Lundqvist (1971, 89-90); Kux and Schenkel (2000, 201).

${ }^{40}$ Haefeli $(1999,179)$.

${ }^{41}$ Which presented its proposals in 1966. SOU 1966:65.

${ }^{42}$ See, e.g., for the Expert Group's composition, see its final report Ds. K 1971:1. In 1978, Volvo employed 47,000 people and Saab-Scania 33,000 in Sweden, SOU 1982:27, 294-95.

${ }^{43}$ SNA, Expertgruppen för att leda utvecklingen på bilavgasområdet [henceforth EGB], box 7, "Redogörelse för verksamheten under tiden 24 november 1965-30 Juni 1966."
} 
Materials Science and Technology (EMPA), which had been created in 1883 to conduct tests on construction materials. ${ }^{44}$ EMPA's work on emissions was therefore one of its many activities and its lack of available staff would often be mentioned as an obstacle in implementing unilateral norms that would require more testing within Switzerland. ${ }^{45}$ To tackle vehicle emissions, the Swedish government, in contrast to its Swiss counterpart, had therefore established a coherent governance apparatus enjoying long-term funding and driven by clear research and policy-making goals by the mid-1960s.

The Swedish Expert Group initially reached consensus on the necessity of developing standards in relation to European norms under development in WP 29 within the UNECE framework. Volvo's representative in the Expert Group stated with satisfaction that the "problem [relating to vehicle emission control] could be dealt with by an impartial institution." ${ }^{46}$ The Swedish Expert Group actively participated in the discussions during the first WP 29 meetings and contributed to the creation of a testing method for Europe. Nevertheless, internal conflicts between the industry and state experts quickly emerged.

The Swedish state experts, notably from the Swedish Environmental Protection Agency (SEPA), believed that emission standards should be set according to the principle of best available technology. ${ }^{47}$ Based on testing by the Studsvik laboratory, the experts concluded that the technology that was necessary to comply with the foreseen US 1968 emission standards represented this technology, estimated to reduce emission of $\mathrm{CO}$ and $\mathrm{HC}$ by 40 percent. $^{48}$ In contrast, the Swedish car industry expressed a strong preference for harmonization with coming European standards, but its views were in the minority within the Expert Group. ${ }^{49}$ In 1968, as the WP 29 was close to agreeing on emission limits for what would become UNECE Regulation 15, the Swedish government adopted national emission standards unilaterally, despite Volvo and Saab-Scania's protests. The new standards were based on the European testing cycle and applicable from model year 1971. Thanks to the independent expertise developed by the Studsvik laboratory, the Swedish government had therefore established sufficient autonomy to act against business interests for these first rounds of norms implementation.

While the Swedish approach to vehicle emission standards setting was technocratic, concerned politicians and citizen initiatives were the driving forces to accelerate the regulation in Switzerland at the beginning of the 1970s. In 1970, a parliamentarian filed a motion asking the federal council to tackle this topic and to study the possibility of implementing US norms. This motion was soon followed by further parliamentary debates, recommending that the Swiss government adapt the regulation of vehicle emissions to the "latest scientific and technical discoveries," to adopt the UNECE Regulation 15 and to mandate Swiss governmental delegates to promote the further reduction of vehicle emissions limits. ${ }^{50}$ In parallel, environmental activists were also putting pressure on the Swiss government to take action on environmental issues through the launch of several popular initiatives. The Swiss political system allowed minority groups to propose a modification of the constitution and to get Swiss citizens to vote on it if they managed to collect 50,000 signatures. ${ }^{51}$ In particular, the so-called "Albatross initiative" launched in 1973 by the Working Group for a Clean Switzerland (Arbeitsgruppe saubere Schweiz), which promoted the adoption of very ambitious emission limits with respect to existing European standards, found enough support in the Swiss population to reach the required number

\footnotetext{
${ }^{44}$ EMPA-History, https://www.empa.ch/web/empa/history, accessed 18 October 2021.

${ }^{45}$ See for instance, R. Müller, Sektionschef, Vertreter der PA bei der WP29, Expertengruppe Fahrzeugkonstruction (WP29) der ECE Sitzungen vom 14.18 März 1977 in Genf, Kurzorientierung über die für uns wichtigsten Geschäfte, 01.04.1977, 7 Archives fédérales suisses [hereafter AF], E3363A\#2006/82\#244*.

${ }^{46}$ Quoted in, SNA, EGB, box 1, meeting minutes 15 December 1965, 2. See also Library of the Swedish Association for Motor Vehicle Manufacturers and Importers (henceforth SAMMI), board minutes, 1 December 1965, 3.

${ }^{47}$ The 1963 Commission had already institutionalized that standards should be set according to the best available technology in the Swedish system governing industrial air pollution. SOU 1966:65.

${ }^{48}$ SEPA's views are expressed in the memo from SEPA's Director General Valfrid Paulsson and Göran Persson, also at SEPA, to the Expert Group. SNA, EGB, box 8, "I anledning av remiss den 6 februari 1968 rörande svenskt förslag till ECE om riktvärden för koldioxid och kolväten i bilavgaser.” See also Ds. K 1968:2, 58-62, 78, 80.

${ }^{49}$ See the SAMMI's response to the Expert Group's proposal, SAMMI, technical memo 49/1968, "Yttrande ang. avgaser från besindrivna bilar."

${ }^{50}$ AF, 10 759. Motion des Nationalrates. Motorfahrzeugabgase, 1 December 1971.

${ }^{51}$ Mach (2006).
} 
of signatures. In response to parliamentary and public pressures, the Swiss government adopted Regulation 15 in 1973, while mandating the establishment of a general road map on emission regulations for 1974. Contrary to what happened in Sweden, this first legislative step was implemented without much opposition from business circles in Switzerland, because firstly, there was no domestic car producer lobby and, secondly, even for other interest groups such as car retailers and oil importers, the UNECE Nr 15 norms mainly represented a freeze of already existing emission levels.

\section{Between cooperation and obstruction: business interests in Sweden and Switzerland}

By the mid-1970, both in Switzerland and in Sweden, emission standards had emerged as a subject of regulation and, consequently, of political struggles for decades to come. Owing to the already institutionalized process of norms setting, the Swedish government again adopted its own standards in 1972. Against fervent opposition from the national industry, the government adopted US 1973 emission and testing standards as a basis for model year $1976 .{ }^{52}$ Moreover, the state continued to finance the Studsvik laboratory and, after the Expert Group's dissolution in 1971, placed it under the auspices of the SEPA. "In international comparison," one of the state experts noted in January 1970, "Sweden is well ahead in this [motor vehicle] air pollution control sector." He continued:

However, it is obvious that the problem is far from solved ... and that motor vehicle air pollution will be the dominant air pollution problem in cities during the 1970s. [A continuation is] therefore urgent ... so that the foundations laid can be used for further restrictions in motor vehicle air pollution. ${ }^{53}$

Moreover, establishing emissions limits according to the best available technology was not sufficient to achieve health and environment goals; the Swedish authorities also needed to develop proper methods to ensure that cars in the market did not emit more than the regulatory prescribed limits. Compliance would therefore become the new political concern in the mid-1970s, with heated discussions taking place between the SEPA and the car industry.

In Switzerland, two alternative regulatory scenarios were on the table. The 1974 federal report, based mainly on the recommendations of the Federal Commission on Air Quality, advocated the implementation of norms that went beyond the existing UNECE limits while attempting to preserve, to the extent possible, a multilateral resolution of the problem. The Albatross initiative was significantly more ambitious, and already in 1978 foresaw the implementation of the $\mathrm{CO}, \mathrm{HC}$, and $\mathrm{NO}_{\mathrm{x}}$ limits that the Federal Council plan devised for 1982. While business interests had been rather quiet on the adoption of the UNECE Regulation 15 thanks to its multilateral and modest nature, these new scenarios would drive their active involvement. Both in Switzerland and Sweden, one of the central questions would be the identification of legitimate experts and whether a hierarchy should be established between different types of expertise.

With respect to in-use compliance, that is regulatory methods to ensure that cars in the market did not emit more than the regulatory prescribed limits, the Studsvik laboratory and the state-owned Motor Vehicle Inspection Company provided expertise that challenged the Swedish car industry. Indeed, while Volvo and Saab-Scania were, in principle, able to fulfill the Swedish emissions requirements thanks to their presence in the US market, the early tests run by the state-owned facilities showed that car models subject to emission requirements emitted more compared to those tested for type approval (certification tests conducted on individual cars of the model intended for sale). In June 1976, for instance, a study showed that 62 percent out of roughly 240 cars of model year 1976 exceeded one or several emission limits for $\mathrm{CO}, \mathrm{HC}$, or $\mathrm{NO}_{\mathrm{x}} \cdot{ }^{54}$ Based on these findings, SEPA staffers, not least those who had worked in the Expert Group, questioned carmakers' goodwill, accusing

\footnotetext{
${ }^{52}$ Ds. K 1971:1, 215, and the Royal Ordinance SFS 1972:596 Bilavgaskungörelsen.

${ }^{53}$ See Göran Persson's letter to the Ministry of Transportation, dated 21 January 1970, 1, in SNA, EGB, box 10.

${ }^{54}$ Several tests since 1972 had shown that cars on the market exceeded regulatory limits. The results from the first tests are summarized in SAMMI, technical memo, 4/1974, "Bilavgaslaboratoriet rörande underhåll och utsläpp."
} 
them of purposefully selling cars with poor emission performance to the market. The SEPA argued that the Swedish approach implied that all cars entering the market had to comply with the regulatory limits, therefore positioning themselves not only as key actors in defining the best available technology, but also as legal experts determining in-use compliance responsibility.

SEPA's legal interpretation was challenged by the Swedish car industry, which argued that these results reflected that car owners had not properly maintained the cars used in the tests and, further, that there was no legal requirement that cars other than those tested for type approval had to comply with regulatory tests. ${ }^{55}$ Engine maintenance was indeed a major issue in controlling emissions and the legal responsibility of carmakers or retailers in ensuring emission control shifted toward car owners once the cars were on the market. ${ }^{56}$ One additional factor that might have contributed to the Swedish industry's resistance to in-use compliance is that no other European country had implemented such requirements. Despite the legal ambiguities, the SEPA threatened to implement a recall system for cases in which certain models failed to meet the standards during spot-checks. ${ }^{57}$ Moreover, these controversies around poor in-use compliance even had a strengthening effect on political commitment to fighting the externalities of vehicle emissions. In October 1976, when a CenterConservative-Liberal coalition managed to oust the Social Democrats who had ruled since 1932, practically all political parties in the parliament had called for additional measures to reduce motor vehicle air pollution, isolating the car industry even further. ${ }^{58}$ There was therefore an agreement beyond partisan divides to improve air quality. On 31 January 1977, Valfrid Paulsson, SEPA's Director General, declared to the Swedish press that "[m]otoring is the greatest environmental problem in our country." In March 1977, the Minister of Transport formed an expert committee, which in September proposed stricter in-use compliance criteria with the goal of incentivizing carmakers to develop better and more durable emissions control systems. ${ }^{60}$

In Switzerland, no such hierarchy existed for state-experts. To study in depth the content of the "Albatross initiative" as well as the proposed roadmap of the 1974 federal report, the Swiss chambers established parliamentary subcommissions. In line with the well-established consultation procedures, so-called interested parties were invited to hearings. ${ }^{61}$ The panel was composed of representatives of the car industry and car retailers, environmental organizations and civil servants working in the various concerned departments of the federal administration. Opinions were rather divergent, with business interest representatives, such as the Vice-President of the truck company Saurer AG and the President of the Union professionnelle suisse de l'automobile, calling into question the technical feasibility of the foreseen emissions limits and emphasizing their potential adverse impact on employment and consumers, while environmental activists regarded them as perfectly viable since Japan and the United States had introduced similar regulations. ${ }^{62}$ During the hearings, all interest groups were considered as legitimate experts and the economic dimension of the norms (higher costs, impact on employment, and trade relations) were assessed as equally important as their technical feasibility and impact on health and environment. The members of the commission also visited the EMPA laboratory, as well as the Saurer truck factory in Switzerland and the Daimler-Benz plant in Stuttgart

\footnotetext{
${ }^{55}$ SAMMI, technical memo, 55/1976, ”Anteckningar från överläggningar och presskonferens 1976-08-19-20 rörande Svensk Bilprovnings avgaskontroller av 1976 års modeller."

${ }^{56}$ On the role of maintenance in emissions control, see, e.g., SAMMI, technical memo, 4/1974, "Bilavgaslaboratoriet rörande underhåll och avgasutsläpp.” On the legal responsibility for emission control, see the Swedish Exhaust Emissions Ordinance $\$ 4$, $\$ 10$ 1972:596.

${ }^{57}$ SAMMI, technical memo, 12/1974, "Kommunikationsdepartementet med uppdrag angående undersökning av luftföroreningsutsläpp för fordon," 2, and Olle Åslander, 1975, ”Nya tag mot bilavgaserna," Miljöaktuellt 6: 3.

${ }^{58}$ In 1974, the Liberals, supported by the Centrists and the Conservatives, introduced a bill regarding adoption of US standards requiring catalysts and a ban on lead. Riksdags Record, Motion 1974:319 (Liberal). In January 1977, the Social Democrats similarly proposed program for phasing out lead and stricter enforcement requirements. Riksdags Record, Motion 1976/77:521 (Social Democratic).

59"Valfrid Paulsson: Bilen det största miljöhotet," Svenska Dagbladet 31 January 1977: 4.

${ }^{60}$ Ds. K 1979:7, 99.

${ }^{61}$ Mach (2006).

${ }^{62}$ Procès-verbal des auditions, Annexe au procès-verbal de la séance du 12-13.11.1976, AF, E3360A\#1988/98\#596*.
} 
Germany. During these visits, the automobile industry was able to convince the parliamentarians that "these factories had been investing huge financial means for a long time for research in gas, smoke and noise emissions." 63

After this information gathering and further debates, the parliamentary subcommissions advised rejecting the Albatross initiative in favor of the limits and timetable of the Federal Council's report and their recommendations were followed by the two chambers. During the parliamentary debates and the political campaign before the Albatross vote, the Federal Councilor Kurt Furgler repeatedly promised that the Swiss government would stick to its 1974 plan, whose limits were similar to the one envisioned by the initiative but would come into effect in 1982 rather than 1978, thereby providing more time to adapt. Car retailers and oil importers, such as the Vereinigung Schweizerischer Automobilimporteure, the Vereinigung unabhängiger Schweizer Importeure von Erdölprodukten, and the Schweizerische. Erdöl-Vereinigung, were also very involved in the political campaign. ${ }^{64}$ They emphasized the potential reduction in car models, the price increase, and the jobs destruction in retail that the initiative might cause, which were compelling arguments in times of a precarious economic climate. Little empirical evidence was provided on the actual economic consequences of the vote, and when numbers were presented they emanated from interest groups and were not sanctioned by independent expertise. The Albatross initiative was ultimately rejected with 61.9 percent of the vote against it in 1977, but many commentators interpreted this outcome as a consequence of the Federal Councils' commitment to take the promised actions against air pollution. ${ }^{65}$ As in Sweden, political expectations on better emission regulation were therefore still high.

\section{Engagement with Europe and the oil issues}

Within the UNECE framework, Switzerland and Sweden were seeking an international consensus to implement stricter norms. Although Sweden and Switzerland advocated the most ambitious standards, the Federal Republic of Germany, the Netherlands, and Norway had over the years pushed for stricter standards, while the representatives of the United Kingdom, France, Italy, Spain, and Yugoslavia were either cautious or hostile to further decreasing emissions limits. ${ }^{66}$ While Sweden from the start was following its own path in terms of regulation, after the 1977 vote time was running out for the Swiss government to fulfil its promises. The Swiss government had committed to the UNECE Regulation 15 and had always emphasized that multilateral solutions should be espoused. Nevertheless, the political and economic context was far from favorable to a new multilateral agreement. The oil crisis made the phasing out of lead difficult, a necessary precondition for the introduction of catalysts, the technology that made US and Japanese norms possible. Moreover, it became increasingly difficult to balance fuel economy and increasingly stringent emission standards for $\mathrm{NO}_{\mathrm{x}}$ especially because tighter control of $\mathrm{NO}_{\mathrm{x}}$ required engines to run rich and thus use more fuel. Finally, the economic crisis and the increased Japanese competition made most European governments quite reluctant to additionally burden their national car manufacturers, which could further jeopardize their market share and threaten related jobs.

Swiss representatives developed coordinated strategies with German negotiators in 1977 because both countries were pushing for stricter regulation for 1982 and shared the view that the best available technology should be implemented. ${ }^{67}$ Nevertheless, decisions had to be unanimous and the UNECE

\footnotetext{
${ }^{63}$ Leuenberger, Proposition de la Commission, Prendre acte du rapport et approuver les propositions du Conseil fédéral, Rapport du Conseil fédéral Gaz d'échappement et bruit des véhicules à moteur, 29.09.1975, AF, E3363A\#2006/82\#244*.

${ }^{64}$ Pitteloud (2020)

${ }^{65}$ Université de Berne, Centre de recherche politique en Suisse, Analyse des votations fédérales du 25 septembre 1977, 5 AF, E3363A\#2006/82\#244*.

${ }^{66}$ Economic Commission for Europe, Inland Transport Committee, Working Party on Road Transport, Group of Experts on the Construction of Vehicles, Group of Rapporteurs on Air Pollution (GRPA), Impact of Road Traffic on Air Quality in Switzerland and Consequences, Transmitted by the Rapporteurs from Switzerland, 24.08.1979, 1 AF, E3363A\#2006/82\#244.

${ }^{67}$ Informationsgespräch zwischen Vertretern der Bundesrepublik Deutschland (Innenministerium und Bundes-Umweltamt) und der Schweiz (Polizeiabteilung und Amt für Umweltschutz) vom Donnerstag, den 1. Dezember 1977, über die gegenseitigen Abgasbekämpfungsprogramme und das Vorgehen auf internationaler Ebene, 2 AF, E3363A\#2006/82\#244*.
} 
regulations therefore advanced at a slow pace. For this reason, it soon became obvious to the Swiss negotiators that no significant progresses would be made in the foreseeable future. ${ }^{68}$ Having no choice but to withdraw from Regulation 15 to fulfil the 1974 federal plan, they explained to their UNECE colleagues:

The proposals submitted by Switzerland and by the Federal Republic of Germany within the framework of the competent committees of the ECE, suggesting that the instructions on exhaust gases in the ECE regulation Nr.15 should be tightened up until 1982 (modification 04), have unfortunately been rejected by the majority of the interested countries as too far-reaching and no acceptable counter-proposals have been made. In view of this situation, the Swiss Federal Counsel has decided on July 11th, 1979 after a detailed examination of the matter, to denounce the application of the ECE-Regulation Nr. $15 .^{69}$

Switzerland thus decided to cease applying Regulation 15 starting in October 1982. Germany could not follow Switzerland's path because the country was a member of the EEC and therefore chose to avoid unilateral norms that could impede free trade within the Common Market. The Swiss "go it alone" decision would raise technical challenges and create some political turmoil with its European trade partners. In this context, finding some support was more than welcome.

Another technical issue was making international cooperation more desirable than ever: The implementation of stricter norms implied the introduction of catalysts, which could only work with unleaded gasoline. The newly elected Swedish Center-Conservative-Liberal government formed the Car Exhaust Emission Committee in June 1977, which, in its preliminary report from 1979, outlined two options: Either Sweden could adopt UNECE Regulation 15, which would not improve urban air quality until 2000, or adopt US parity standards assumed to require catalytic converters and unleaded gasoline. ${ }^{70}$ It was clear that US parity standards were preferable from an environmental perspective, not least because lead is a serious neurotoxin. Thus, introducing catalysts and unleaded gasoline would have strengthened the health and environmental benefits of the new emissions limits. However, it was necessary that unleaded fuel be available not only in Sweden, but in several other countries to allow for cross-border transportation and scale economies for the expensive catalyst technology. To achieve domestic goals on motor vehicle air pollution control, international coordination was key. Sweden as well as Switzerland therefore needed foreign allies.

\section{The inauguration of a Swiss-Swedish approach to vehicle emissions}

Sweden made clear within the WP 29's specialist Group of Rapporteurs on Air Pollution, GRPA, that it was in favor of international cooperation, especially because of the limited possibilities of introducing stringent regulations on a unilateral basis if unleaded gasoline was not available in Europe. When Switzerland was still hesitating about withdrawing from the UNECE regulation, the Swedish representatives made the following statement:

Sweden is positively interested in a coordination with other countries in Europe when prospects exist for a more common agreement on strengthened regulations regarding emissions of air pollutants from vehicles... The lead additives in gasoline present an important aspect on air pollution from vehicles.... Our goal is a lead-free fuel. As you know, the possibility of making full use of advanced emission control technologies also depends on the amount of lead in the fuel. The

\footnotetext{
${ }^{68}$ R. Müller, Sektionschef, Vertreter der PA bei der WP29, Expertengruppe Fahrzeugskonstruction (WP29) der ECE Sitzungen vom 14.18 März 1977 in Genf, Kurzorientierung über die für uns wichtigsten Geschäfte, 01.04.1977, 7 AF, E3363A\#2006/ $82 \# 244^{*}$.

${ }^{69}$ Economic Commission for Europe, Inland Transport Committee, Working Party on Road Transport, Group of Experts on the Construction of Vehicles, Group of Rapporteurs on Air Pollution (GRPA), Impact of Road Traffic on Air Quality in Switzerland and Consequences, Transmitted by the Rapporteurs from Switzerland, 24.08.1979, 1 AF, E3363A\#2006/82\#244.

${ }^{70}$ SOU 1979: 34, 88.
} 
present and future emission control requirements in the US and Japan are based on the use of lead-free gasoline. Such fuels are not now commonly available in Europe. ${ }^{71}$

Swiss representatives therefore saw an opportunity to develop cooperation with Sweden, which was not its usual preferred European partner. Indeed, with respect to economic matters, Switzerland usually tended to cooperate more closely with Austria and Germany, while Sweden's economic and social policies were aligned with those of other Scandinavian countries. ${ }^{72}$ From the mid-1970s, the Swiss, German, and Austrian economic and finance ministers, as well as the secretaries of the main business interest associations, were meeting on a regular basis to remove trade barriers. ${ }^{73}$ The Swiss-Swedish rapprochement with respect to environmental standards was in this respect an unexpected collaboration, mainly led by the environmental bodies of the two countries.

In 1979, the Swedish government transferred the responsibility for issuing new regulations from the National Road Traffic Safety Agency to SEPA, which meanwhile was tasked with finding at least one additional country with which to coordinate the work to develop stricter standards. ${ }^{74}$ Switzerland and Sweden, seated next to each other during the GRPA sessions, had often found agreement on key issues and began entertaining the idea of initiating formal cooperation. ${ }^{75}$ In 1980 SEPA and Switzerland began developing the joint A10 regulation, applicable from model year 1983. The regulation built on the Swedish standards for model year 1976 but incorporated stricter in-use compliance and enforcement criteria that had long been discussed in Sweden. Their representatives met in Geneva and Stockholm and compared their respective regulations, the role and means of their environmental agencies, and exchanged knowledge on technical possibilities, testing and enforcement methods. ${ }^{76}$ During these international talks, in contrast to national negotiations, national business interests were not represented.

For the Swiss representatives, especially those of the Swiss Federal Office for the Environment (FOEN), a Swiss-Swedish collaboration was perceived as a great opportunity because "Sweden had been addressing the vehicle emissions and air pollution problems for much longer and with more staff and financial means." ${ }^{\text {77 }}$ The Swedish Car Exhaust Emission Commission expressed the view that cooperation with Switzerland could "widen the market for emission control technology" used in Sweden and potentially lead to lower administrative costs. ${ }^{78}$ Yet the Swedish and international car industry had raised consistent criticism against the Swedish government for its penchant for unilateral regulation of vehicle emissions. ${ }^{79}$ The Swedish market only constituted two percent of the European car market in 1980. Harmonizing regulations with Switzerland was not a substantial response to this critique, considering that both countries represented roughly 5 percent of the Western European market, while Regulation 15 governed more than 90 percent of the Western European car trade. ${ }^{80}$ There is, however, evidence that Swedish policy makers believed that Sweden

\footnotetext{
${ }^{71}$ GRPA (ECE), Eighteenth Session, Statement by the Swedish Delegation, 06.02.1978, AF, E3363A\#2006/82\#244*.

${ }^{72}$ Pontusson (2005).

${ }^{73}$ Pitteloud (2021, 6).

${ }^{74}$ SAMMI, technical memo, 54/1979, "Naturvårdsverket föreskrivande myndighet på bilavgasområdet," and document supplied to the authors by Olle Åslander, "Några highlights från Olle Å:s jobb för en bättre miljö," dated 16 December 2005.

${ }^{75}$ In alphabetical order, the Swedish and Swiss delegations were seated next to each other on the GRPA sessions. E-mail correspondence between Olle Åslander and the authors.

${ }^{76}$ Bundesamt für Umweltschutz, Bericht über die Aussprache zwischen Behördenvertretern Schwedens und der Schweiz über Fragen der Autoabgasen vom 19. Bis 21. März 1980 in Stockholm, AF, E3363A\#2006/82\#244.

${ }^{77}$ Ibid.

${ }^{78}$ See the Car Exhaust Emission Committee's referral regarding the Swiss regulation, SNA, Bilavgaskommittén, box 10, “TBT/ EFTA; ang schweizisk notifikation avseende ändring av vissa motorfordonsbestämmelser," dated 8 May 1981.

${ }^{79}$ Not least during the summer of 1978, where SAMMI, Volvo, Saab-Scania, and union representatives met with the government to make it "realize the consequences of authorities' actions taken against motoring." See SNA, Bilavgaskommittéens, box 12, "Bilindustriföreningen: Nu måste statsmakterna inse följderna av myndigheternas aktioner mot bilismen."

${ }^{80}$ Calculated based on information on passenger car registrations from World Motor Vehicle Data 1987 as well as country application and cessation of Regulation 15 from https://treaties.un.org/Pages/ViewDetails.aspx?src=TREATY\&mtdsg_no=XIB-16-15\&chapter=11\&clang=_en, accessed 14 October 2019.
} 
could blaze a trail for other countries by its actions. ${ }^{81}$ The fact that Switzerland chose to collaborate with Sweden on vehicle emissions regulation indicates some success for this strategy.

Relying on the Swedish expertise and experience was also a way for the FOEN to counteract pressure coming both from business groups and from within other departments of the federal administration to delay and dilute the norms. At the request of the Federal Council, an interdepartmental working group that gathered representatives of the FOEN, the Federal Department of Justice and Police (FDJP), and the Division of Commerce, was created in 1978 to make concrete proposals for the emissions implementation and to integrate all relevant dimensions in the proposals such as environment and health issues, but also potential oil supply, enforcement, and trade-related problems. ${ }^{82}$ The views expressed within this working group by the civil servants from different departments reflected the divergence existing between environmental organizations and business interests, with the Division of Commerce, which had many ties to Swiss business interest associations, ${ }^{83}$ insisting on preserving jobs and trade relations while the FOEN considered the implementation of the 1974 Federal Council plan perfectly enforceable by 1982 without any further delays. ${ }^{84}$ Moreover, the Division of Commerce advocated further integration of the views of "experts"-meaning representatives of car and oil importers-in the discussions and for taking into consideration Switzerland's previous efforts to diminish trade barriers in Europe. ${ }^{85}$ The interdepartmental working group ultimately elaborated three scenarios, which were submitted to interest groups in Switzerland in line with the usual corporatist procedure and, in addition, to Swiss EFTA and EEC trade partners. ${ }^{86}$ While pressures from business interest were strong, with warnings of trade retaliations coming even from foreign organizations such as the Committee of Common Market Automobile Constructors (CCMC) and the Bundesverband der Deutschen Industrie (BDI), ${ }^{87}$ the public promises made during the Albatross campaign, as well as the commitment to collaborate with Sweden, prevented any abandonment of the envisioned 1974 Swiss regulations. A compromise was finally found with a two-step implementation, with the enforcement of the A10 regulation in 1982 and of the US standards for model year 1977-79 in 1986. The second step implied standards stricter than Swedish standards for which, according to Swedish governmental and car industry experts, catalysts represented the best available technology. However, the Federal Council did not, at the same time, mandate introduction of unleaded gasoline, rendering commercial catalysts unviable. Thus, the car industry fiercely opposed having to develop new technologies for the relatively small Swiss market. ${ }^{88}$

In Sweden, the SEPA issued the A10 regulation as a matter of administrative decree in June 1981. The SEPA's collaboration with Swiss agencies had blindsided the Swedish car industry, which previously had been directly involved in developing Swedish emission standards. Moreover, Western car markets were struggling in the early 1980s because of the economic turmoil brought by the 1979-80 oil price shock, leading both Volvo and Saab-Scania to report losses. The car industry called on the government to overrule the A10 regulation, arguing instead for harmonizing Swedish regulation with the less stringent UNECE Regulation 15. Håkan Frisinger, the CEO of Volvo's passenger car operations sharply criticized the government's "lack of a comprehensive approach on car regulation," and

\footnotetext{
${ }^{81}$ As Sweden's Minister of Transportation, Svante Lundqvist, told the Swedish Association of Motor Vehicle Manufacturers and Importers in 1969. SAMMI, board minutes, 14 April 1969, 7.

${ }^{82}$ Interdepartementale Arbeitsgruppe „Lärm und Abgas der Motorfahrzeuge“; Zusammenfassendes Protokoll der ersten, konstituierenden Sitzung vom 27. April 1978 in Bern, bei der Eidg. Polizeiabteilung, AF, E3363A\#2006/82\#244.

${ }^{83}$ Dirlewanger et al. $(2004,26)$.

${ }^{84}$ Eidg. Amt für Umweltschutz, Arbeitsgruppe Abgase und Lärm der Motorfahrzeuge, 18.12.1978, an die Eig. Polizeiabteilung, an die Eidg. Handelsabteilung, AF, E3363A\#2006/82\#242*.

${ }^{85}$ Interdepartementale Arbeitsgruppe „Lärm und Abgase der Motorfahrzeuge,“ Protokoll der 5. Sitzung vom 20. December 1978, AF, E3363A\#2006/82\#245*.

${ }^{86}$ Dienst für internationale Industrie und Energiefragen, Notiz an Herrn Botschafter F. Rothenbühler, im Hinblick auf bilaterale Kontakte mit der BRD, Abgasvorschriften für leicht Motorwagen, 19.07.1979, AF, E7115A\#1990/60\#70*.

${ }^{87}$ B. Wehrli, SHIV, Entwurf für Brief an Herrn Dr. S. Mann, 22.08.1982, Archiv für Zeitgeschichte [hereafter AfZ], IB Vorort-Archiv, 117.3.2.

${ }^{88}$ SOU 1983:27, 27, 46, 186-87, 198, 200, 202, 280, 283, 344-45.
} 
claimed, "the government ... has got on a collision course with the car industry." 89 The Federation of Swedish Industries also criticized the government, cautioning that Sweden might be "placed on the Japanese side of the trade war" against the EEC, owing to previous criticism by the Commission aimed at Sweden's proposal to implement the A10 regulation. ${ }^{90}$ After a preliminary decision in February 1982, confirmed in August the same year, the Swedish government pushed out the mandatory implementation of the new norms until 1985 instead of 1983, relaxed noncompliance penalties, and withdrew some of SEPA's discretionary powers. Still, the government considered the Swedish car industry's complaints invalid, arguing that additional measures were indeed necessary. ${ }^{91}$

Ultimately, if both Swiss and Swedish regulations were delayed and diluted due to the pressure of the car industry and of the EEC countries, transforming their "go it alone" approach to a bilateral approach enabled them to pursue their forerunner strategies. Their collaboration at the international level was strengthening the legitimacy of their environmental experts. Nevertheless, the problem of the unleaded gasoline supply was still on the horizon and demonstrated the limits of state' agency in an interdependent economic world.

\section{The Stockholm Group}

At the beginning of the 1980s, the increased political awareness of the acid rain problem provided a window of opportunity to solve the unleaded gasoline supply issue at the European level. In central Europe, scientists linked acid rain to the forest dieback phenomenon-Waldsterben-while Scandinavian countries were suffering from various forms of acidification problems. Sulfur dioxide $\left(\mathrm{SO}_{2}\right)$ emissions, primarily emitted from oil and coal combustion in industrial processes or domestic heating, were the main pollutants implicated in creating acid rain. However, nitrogen dioxide $\left(\mathrm{NO}_{2}\right.$, a pollutant included under the generic term $\mathrm{NO}_{\mathrm{x}}$ ), which was largely emitted by cars and other motor vehicles, also caused acidic precipitation. Because $\mathrm{NO}_{2}$ (but also $\mathrm{SO}_{2}$ ) could travel and create acidification far from the point of emission, this increased the scale of the motor vehicle air pollution problem-from the local or national, toward the regional and international.

Aware that the introduction of unleaded gasoline in Europe was a strategic consideration to allow advanced emission control with catalysts and thus effective control of $\mathrm{NO}_{\mathrm{x}}$ emissions, and owing to the slow progress by GRPA, the Swiss-Swedish representatives organized smaller meetings with other potential interested partners, such as the Norwegians and the Germans. ${ }^{92}$ Both Sweden and Switzerland indeed envisioned that if their cooperation proved successful, "chances were high that Norway would join them, which would mean that EFTA countries would have the same emission regulation" and that "it was even possible that this regulation would constitute an attractive alternative to the current ECE regulation for Germany and the Netherlands." 93 Behind Sweden and Switzerland, West Germany had tabled the most ambitious proposals to tighten vehicle emission standards in Europe, while the Netherlands had called for stricter standards to limit $\mathrm{NO}_{\mathrm{x}}$ emissions and combat regional air pollution. ${ }^{94}$

Lead emissions from cars had been a contested issue within the EEC since 1971 when West Germany decided to lower the permissible lead content of gasoline in two steps (1972 and 1976). ${ }^{95}$ Conflicts emerged over interpretations on the science of lead pollution, while Germany's decision

\footnotetext{
${ }^{89}$ Letter from Frisinger to the Minister of Agriculture, the Minister of Industry, and the Minister of Trade, in SEPA, Generaldirektörens ämnesordnade handlingar, bilavgaser [henceforth GDB], box F30:45, "Angående svenska avgasnormer."

${ }^{90}$ SEPA, GDB, box F30:45, "Bilavgassamarbetet med Scweiz," 2, dated 8 March 1982.

${ }^{91}$ See the Swedish government's response to the Commission in SAMMI, board memo, 40/1982, "Bilavgasfrågan."

${ }^{92}$ Bundesamt für Umweltschutz, Bericht über das Informationsgespräch zwischen Vertretern von Schweden, Norwegen, Kanada und der Schweiz über Fragen des Bleibenzins und der Autoabgase vom 15 February 1980 in Genf, AF, E3363A\#2006/82\#244.

${ }^{93}$ J. Kellenberger, Bundesamt für Umweltschutz, Bericht über die Aussprache zwischen Behördenvertretern Schwedens und der Schweiz über Fragen der Autoabgasen vom 19. Bis 21. März 1980 in Stockholm, 25 AF, E3363A\#2006/82\#244.

${ }^{94}$ SNA, KAIS, dossier F2, box 84, "Report of the Group of Experts on Its Thirty-Eight Session (16-20 October 1972)," 4; SAMMI, technical memo, 18/1978, "Rapport från ECE:s rapportörgrupp för bilavgaser," 5.

${ }^{95}$ To 0.40 grams per liter in 1972 and 0.15 grams per liter in 1976.
} 
would raise trade barriers within the Common Market. Moreover, lead was used in gasoline to increase octane ratings, allowing for higher cylinder compression and thus lowering fuel consumption. Efforts to phase out lead clashed with the goals to conserve energy. In 1978, the Council issued the so-called Lead Directive, which set an upper and lower limit on the amount of lead in gasoline (0.15-0.40 grams per liter), applicable from 1981. On opposing sides, West Germany envisioned a ban on leaded gasoline to allow the use of catalysts, while the United Kingdom opposed banning lead, claiming a lack of scientific evidence on its health hazards. ${ }^{96}$

In early 1980, West Germany became increasingly vocal in its criticism of the slow development within the UNECE framework, threatening to go it alone if other EEC countries did not adopt higher targets on vehicle emission control. ${ }^{97}$ Swedish government representatives and representatives of the German Ministry of the Interior further discussed a joint program in late 1981, to which Austria, the Netherlands, Norway, and Switzerland could be invited. With the support of these countries, the German representatives envisioned that it might be possible for West Germany to change the EEC standard. ${ }^{98}$ In April 1983, the British government finally accepted a proposal from the Royal Commission on Environmental Pollution to initiate negotiations with the Commission on removing lead within the EEC. ${ }^{99}$ The British shift on lead quickly created consensus on removing lead within the Common Market. The Waldsterben issue had taken a central place in West German political debate, and quickly became a priority for the new Centre-Right coalition government. ${ }^{100}$ Through a preliminary decision in July 1983, confirmed in October the same year, West Germany announced the introduction of unleaded gasoline as well as US standards for model year 1983 that would require catalysts in Germany by 1986, meanwhile confirming the government's intention to seek a common solution with other EEC states. ${ }^{101}$

The Swedish car industry had been fervently opposed to proposals to introduce unleaded gasoline and US parity standards, so much so that the Swedish Association of Motor Vehicle Manufacturers and Importers organized a public campaign between late 1979 and 1983 on a scale never before seen in Sweden. ${ }^{102}$ West Germany's position regarding standards was important for the Swedish car industry owing to the size of the German car market. With the West German decision, the Swedish car industry's opposition to stringent standards all but vanished and turned instead toward cautious support for the Swedish government's attempts at coordinating stringent environmental requirements with other countries in Europe. ${ }^{103}$

During the fall of 1983, West Germany and Sweden initiated expert-level meetings on technical coordination of catalyst standards and unleaded gasoline introduction. The German government described their decision as a Grundsatz-Beschluss, signaling that radical action was necessary. ${ }^{104}$ By showing resolve, the German government inspired also Denmark, Finland, and Norway who, together with Sweden, announced their countries' intention to introduce unleaded gasoline and catalysts as soon as possible, as well as to work together to push Europe in the same direction. ${ }^{105}$ The major roadblock toward implementing catalysts and unleaded gasoline in the Scandinavian countries was EEC regulation banning unleaded gasoline. In May 1984, however, the Commission proposed permitting

\footnotetext{
${ }^{96}$ On this, see Haigh (1998).

${ }^{97}$ Expressed by Gerhart Baum, the Minister of Interior, in a speech during a hearing by the Council of Europe on the car and the environment 12 February 1980, SNA, Bilavgaskommittén, box 11, "Ansprache des Bundesministers des Innern, Gerhart Rudolf Baum," 17-18.

${ }^{98}$ Memo by Carl-Henrik Hamrin at the Swedish Embassy in Bonn in SEPA, GDB, box F30:45, "Besök på inrikesministeriet (BMI) den 8 december 1981-bilavgasfrågan."

${ }^{99}$ Haigh $(1998,139)$.

${ }^{100}$ Wurzel $(2002,116-117)$.

${ }^{101}$ Ibid, 115 .

${ }^{102}$ Primarily, the industry opposed the government's indication of going it alone in terms of unleaded gasoline as well as car taxation issues. Näsman (2021, 254-58), discusses the motives, outcomes, and implementation of the industry's campaign.

${ }^{103}$ SAMMI, technical memo, 44/1983, "Bilvgasfrågan kräver omedelbara initiativ."

${ }^{104}$ SNA, Utrikesdepartementets arkiv, dossier H44, box 9, "Bilavgasfrågan. Samtal med Västtyskland."

${ }^{105}$ Statement by the Scandinavian ministers of the environment, attached to memo by Bo Assarson, in SNA, Industri- och näringsdepartementets arkiv, dossier F5, box 145, "PM angående Birgitta Dahls besök i Västtyskland."
} 
member states to introduce unleaded gasoline by 1986, which set in motion intensive efforts to coordinate proactive states outside and inside the Common Market.

Following the EEC decision in May 1984, Svante Lundkvist, Sweden's Minister of Agriculture, and Friedrich Zimmerman, Germany's Minister of the Interior, agreed to cooperate closely and, together with other interested states, negotiate a common approach to introducing unleaded gasoline and stringent standards as soon as possible. ${ }^{106}$ In the summer, under the auspices of the UNECE Convention on Long-Range Transboundary Air Pollution, Lundkvist invited the Scandinavian countries, Austria, Canada, France, the Netherlands, Switzerland, and West Germany to expert meetings to discuss limiting $\mathrm{NO}_{\mathrm{x}}$ emissions by introducing the best available technology for limiting vehicle emissions (threeway catalysts) and unleaded gasoline. At the first meeting in August 1984, France dropped out while Lichtenstein joined what has become known as the Stockholm Group. The remaining ten countries agreed to cooperate on introducing requirements equivalent to US standards for model year 1983 and unleaded gasoline as quickly as possible. ${ }^{107}$ In doing so, Zimmerman told Lundkvist, the Stockholm group had taken on a "pilot function" (Pilotfunktion) in improving air quality in Europe. ${ }^{108}$ At the heart of the Stockholm Group's activates was the development of a framework regulation that would allow a coordinated approach to implementation of harmonized rules by the Stockholm Group countries. Swedish experts held main responsibility for designing a "Master Document," containing technical provisions that were based on US standards and testing procedures for 1983, but adapted for European legal requirements. ${ }^{109}$

In March 1985, the European Environmental Ministers adopted the Commission's proposal, thus permitting member states in the Common Market to introduce unleaded gasoline immediately, which up until then they had not been permitted to do. This decision cleared the road for the Stockholm Group countries. Having already prepared the introduction of unleaded gasoline and strict standards, Austria, Norway, Switzerland and Sweden that all had issued provisions under the framework of the Master Document by 1987, while Denmark and Finland had done so by 1989. Switzerland introduced mandatory US parity standards from October 1987, Austria from January 1988, and Sweden from the fall of $1988 .{ }^{110}$ The EEC lagged behind and adopted US standards for large cars in 1988, small cars in 1989, and for all cars 1991. Hence, from October 1993, all cars entering the Single Market in practice required three way-catalysts to comply, roughly five years after Sweden, Switzerland, and Austria.

Liefferink argued that the Stockholm Group had an indirect impact on the EEC policy process "by once more showing the priority given by Denmark, Germany and the Netherland to stricter standards." ${ }^{111}$ We complement this perspective by stressing the Stockholm Group's "pilot function" in the European political process. Through 'hidden' processes related to the circulation of technical knowledge, the Stockholm group managed to show that cutting emissions was, in fact, an attainable goal while simultaneously coordinating action between proactive countries to facilitate realization of this goal.

\section{Conclusions}

By jointly analyzing the Swiss and the Swedish experience of vehicle emission regulation during the 1970s and 1980s, the article has shed lights on the importance of power dynamics around expertise creation and the circulation of knowledge. It has also shown that it is crucial to look beyond the

\footnotetext{
${ }^{106} \mathrm{SEPA}$, Generaldirektörens ämnesordnade handlingar, svavel, box F30:46, "Gemensam presskommuniké med anledning av besöket av den svenske jordbruksministern Svante Lundkvist hos förbundsinrikesministern Dr. Friedrich Zimmerman i Bonn 30 maj 1984."

${ }^{107}$ Memo by A Boehman, dated 4 September 1984, in SNA, Jordbruksdepartementet, internationella sekretariatet [henceforth JIS], dossier F1, box 24, "Internationellt möte om bilavgaser," and SAMMI, technical memo, 36/1984, "Internationella överläggningar 1984-08-24 om avgasbestämmelser och blyfri bensin.”

${ }^{108}$ Letter from Zimmerman to Lundqvist, dated 31 July 1984, in SNA, JIS, dossier F1, box 24.

${ }^{109}$ Austrian and Swiss experts also helped with developing the Master Document. SNA, JIS, dossier F1, box 25, "Expertentreffen betreffend Motorfahrzeugabgase in Bern," dated 4 July 1985.

${ }^{110}$ SAMMI, annual report 1986, 9; idem, annual report 1987, 10; SOU 1989:84, 16.

${ }^{111}$ Liefferink (1996, 107).
} 
EEC to understand the early steps of emissions regulations in Europe during the postwar period. The UNECE was the main multilateral negotiation arena in the 1960s, and when European multilateralism ran out of steam in the 1970s, further emissions regulations occurred at the margins of the EEC in countries like Switzerland and Sweden.

Firstly, the analysis has shown that despite similar political ambitions, Switzerland and Sweden had different approaches to the production of expertise, which partly explains the discrepancy in political outcomes. The Swedish government, thanks to the funding of the Studsvik laboratory, enabled state environmental agencies to dictate the regulatory agenda and to ensure in-use compliance, even in the face of strong opposition from the Swedish car industry. Business power proved therefore rather limited during the first phase of emissions abatement. In the Swiss case, while there were no major national carmakers, business groups such as oil importers and car retailers played an important role because of the institutionalized procedure of consultations. Expertise creation was therefore little more than a consensus among a variety of diverging interests. Additionally, pro business state agencies such as the Division of Commerce favored trade considerations above environmental goals and challenged the expertise of the Swiss Federal Office for the Environment. The use of popular initiatives by activists and the will of the Federal Council to retain political legitimacy nevertheless prevented a total abandonment of Switzerland's own national regulatory agenda.

Secondly, this article has shown the importance of Swiss and Swedish cooperation to counteract business influence at the national level as well as pressure from international business interest associations and from EEC countries. Indeed, thanks to this bilateral knowledge circulation, state experts from environmental agencies gained in legitimacy. Moreover, the prospect of the domino effect, with a progressive norm integration at the margins of the EEC, proved to be helpful in multilateral negotiations, not only for Switzerland and Sweden but also for Germany. Yet, the article has also highlighted that political decisions (or the lack thereof) operated as a roadblock to achieving Swiss and Swedish goals in relation to the availability of unleaded gasoline. Thus, here again, the Swedish technical knowledge and its circulation within the Stockholm Group, helped experts from other EEC countries to advocate the introduction of unleaded gasoline in Europe. In the end, Sweden and Switzerland's cooperation built on shared goals to reduce motor vehicle air pollution as quickly as possible for the sake of public health and the natural environment, contributed to paving the way for advanced emission control technology in Europe.

Acknowledgements. The authors would like to thank Patrick Fridenson, Samuel Klebaner, and Grace Ballor for participating in the workshop on environmental standards and business at the Business History Conference in 2021, from which this article has developed. We would also like to thank Geoffrey Jones for offering constructive criticism on a late version of this article, as well as two anonymous reviewers.

\section{References}

Arp, Henning. 1995. "Multiple Actors and Arenas: European Community Regulation in a Polycentric System: A Case study on Car Emission Policy.” Ph.D. diss., European University Institute, Florence.

Ballor, Grace. 2021. "Trade and the Single Car Market: The EC-Japan Elements of Consensus, 1985-1999." Harvard Business School Working Paper 21 (145): 1-27.

Berg, Wolfgang. 1985. "Evolution of Motor Vehicle Emission Control Legislation in Europe-Leading to the Catalyst Car?” SAE Special Publications: Motor Vehicle Air Pollution Controls: A Global View: 17-38. Society of Automotive Engineers.

Bergquist, Ann-Kristin. 2007. "Guld och gröna skogar? Miljöanpassningen av Rönnskärsverken 1960-2000.” Ph.D. diss., Umeå University, Umeå.

Bergquist, Ann-Kristin, and Mattias Näsman. 2021. "Safe before Green! The Greening of Volvo Cars 1970s-1990s." Enterprise and Society: 1-31. Published online, https://www.doi.org/10.1017/eso.2021.23.

Boehmer-Christiansen, Sonja, and Helmut Weidner. 1995. The Politics of Reducing Vehicle Emissions in Britain and Germany. Pinter. Culpepper, Pepper D. 2015. "Structural Power and Political Science in the Post-Crisis Era." Business and Politics 17 (3): $391-409$.

Dirlewanger, Dominique, Sébastien Guex, and Gian Franco Pordenone. 2004. La politique commerciale de la Suisse de la Seconde Guerre mondiale à l'entrée au GATT (1945-1966). Chronos Verlag.

Ds. K 1968:2. Avgaser från bensindrivna bilar: utredning med förslag till åtgärder. Ministry of Transportation.

Ds. K 1971:1. Luftföroreningar genom bilavgaser. Slutbetänkande av Kommunikationsdepartementets ledningsgrupp rörande utvecklingsarbetet på bilavgasområdet. Ministry of Transportation.

Ds. K 1979:7. Fordon i föreskrivet skick: Delbetänkande av typbesiktningsutredningen. Ministry of Transportation. 
Eichenberger, Pierre, and André Mach. 2011. "Organized Capital and Coordinated Market Economy: Swiss Business Interest Associations between Socio-economic Regulation and Political Influence.” In Switzerland in Europe: Continuity and Change in the Swiss Political Economy, edited by Christine Trampusch and André Mach. Routledge, 85-103.

Esty, Daniel C., and Damien Geradin 1997. "Market Access, Competitiveness, and Harmonization: Environmental Protection in Regional Trade Agreements.” Faculty Scholarship Series 448: 265-336.

Foucault, Michel. 1980. Power/Knowledge: Selected Interviews and Other Writing 1972-1977. Prentice Hall.

Fuchs, Doris. 2007. Business Power in Global Governance. Lynne Rienner Publishers.

Gerard, David, and Lester B. Lave. 2005. "Implementing Technology-Forcing Policies: The 1970 Clean Air Act Amendments and the Introduction of Advanced Automotive Emissions Controls in the United States." Technological Forecasting and Social Change 72: 761-78.

Haefeli, Ueli. 1999. "Luftreinhaltepolitik im Straßenverkehr in den USA, in Deutschland und in der Schweiz. Ein Vergleich der Entwicklung nach 1945." Traverse, Zeitschrift für Geschichte (6) 2: 171-91.

Haigh, Nigel. 1998. "Challenges and opportunities for IEA - science-policy interactions from a policy perspective." Environmental Modeling \& Assessment 3: 135-142.

Hall, Peter, and David Soskice. 2001. Varieties of Capitalism: The Institutional Foundations of Comparative Advantage. Oxford University Press.

Högselius, Per. 2013. Red Gas: Russia and the Origins of European Energy Dependence. Palgrave Macmillan.

Högselius, Per, Arne Kaijser, and Erik van der Vleuten. 2016. Europe's Infrastructure Transition: Economy, War, Nature. Palgrave Macmillan.

Kaiser, Wolfram, and Johan Schot. 2014. Writing the Rules for Europe: Experts, Cartels, and International Organizations. Palgrave Macmillan.

Katzenstein, Peter J. 1985. Small States in World Markets: Industrial Policy in Europe. Cornell University Press.

Klebaner, Samuel. 2018. "Dynamiques réglementaires et planification des firmes: les leçons des limites européennes d'émissions de polluants dans l'automobile. “ Ph.D. diss., Bordeaux University, Bordeaux.

Klebaner, Samuel, and Sigfrido Ramírez Pérez. 2019. "Managing Technical Changes from the Scales of Legal Regulation: German Clean Cars against the European Pollutant Emissions Regulations in the 1980s." Management \& Organizational History 14 (4): 442-68.

Krebs, Stefan. 2012. "Standardizing Car Sound - Integrating Europe? International Traffic Noise Abatement and the Emergence of a European Car Identity, 1950-1975.” History and Technology 28 (1): 25-47.

Krier, James E., and Edmund Ursin. 1977. Pollution and Policy-A Case Essay on California and Federal Experience with Motor Vehicle Air Pollution 1940-1975. University of California Press.

Kux, Stephan, and Walter Schenkel. 2000. "Switzerland: From Pusher to Laggard in Clean Air Policy." In International Environmental Agreements and Domestic Politics-The Case of Acid Rain, edited by Arild Underdal and Kenneth Hanf: 199-223. Routledge.

Lemaigre, Pierre. 1966. "La pollution de l'air par les véhicules automobiles." Annales des mines 1 (II): 143-68, 29-54.

Liefferink, Duncan. 1996. Environment and the Nation State: The Netherlands, the EU and Acid Rain. Manchester University Press.

Lindvall, Johannes, and Bo Rothstein. 2006. “Sweden: The Fall of the Strong State.” Scandinavian Political Studies 29 (1): 47-63.

Lundqvist, Lennart. 1971. "Miljövårdsförvaltning och politisk struktur.” Ph.D. diss., Uppsala University, Uppsala.

Lundqvist, Lennart. 1980. The Hare and the Tortoise: Clean Air Policies in the United States and Sweden. University of Michigan Press.

Mach, André. 2006. La Suisse Entre Internationalisation et Changements Politiques Internes: La Législation Sur Les Cartels et Les Relations Industrielles Dans Les Années 1990. Rüegger.

Mach, André, and Christine Trampusch. 2011. "Introduction." In Switzerland in Europe: Continuity and Change in the Swiss Political Economy, edited by Christine Trampusch and André Mach: 1-8. Routledge.

Mattioli, Giulio, Cameron Roberts, Julia K. Steinberger, and Andrew Brown. 2020. "The Political Economy of Car Dependence: A Systems of Provision Approach.” Energy Research \& Social Science 66: 101486.

McCarthy, Tom. 2007. Auto Mania: Cars, Consumers, and the Environment. Yale University Press.

Misa, Thomas J., and Johan Schot. 2005. "Inventing Europe: Technology and the Hid-den Integration of Europe." History and Technology 21 (1): 1-19.

Moguen-Toursel, Marine. 2003. "Strategies of European Automobile Manufacturers Facing Community Environmental Standards." Business and Economic History On-Line 1: 1-28.

Moguen-Toursel, Marine. 2010. "Defining a European Vehicle: Community Standards as Integration Tools or Trade Barriers for European Enterprises?” In The European Enterprise: Historical Investigation into a Future Species, edited by Harm G. Schröter, 67-80. Springer.

Moguen-Toursel, Marine. 2011. "Vers une co-production des standards automobiles environnementaux au plan communautaire?” In La Responsabilité Sociale de l’Entreprise: Nouvelle régulation du capitalisme?, edited by Frédéric Chavy, Nicolas Postel, Richard Sobel, and Didier Cazal, 259-70. Presses universitaires du Septentrion.

Näsman, Mattias. 2021. The Political Economy of Emission Standards: Politics, Business and the Making of Vehicle Emission Regulations in Sweden and Europe, 1960-1980s. Ph.D. diss., Umeå Studies in Economic History 51, Umeå University.

Neumaier, Christopher. 2014. "Eco-Friendly versus Cancer-Causing: Perceptions of Diesel Cars in West Germany and the United States, 1970-1990.” Technology and Culture 55 (2): 429-60. 
Nye, Joseph S. 2004. Soft Power: the Means to Success in World Politics. PublicAffairs.

Pitteloud, Sabine. 2020. "Delay and Dilution in the Implementation of Environmental Norms: Business Groups and the Regulation of Car Emissions in Switzerland in the 1970s-1980s.” Working Paper, Paul Bairoch Institute of Economic History.

Pitteloud, Sabine. 2021. "Let's Coordinate! The Reinforcement of a 'Liberal Bastion' within European Industrial Federations, 1978-1987.” Business History, 1-21.Published online, https://doi.org/10.1080/00076791.2021.1905797.

Pontusson, Jonas. 2005. Inequality and Prosperity: Social Europe vs. Liberal America. Cornell University Press.

Ramírez-Pérez, Sigfrido. 2009. "International Business Networks Propagating EC Industrial Policy: The Role of the Committee of Common Market Automobile Constructors." In The History of the European Union: Origins of a Trans- and Supranational Polity 1950-1972, edited by Wolfram Kaiser, Birgitte Leucht, and Morten Rasmussen, 74-92. Routledge.

Ramírez-Pérez, Sigfrido. 2010. "Automobile Standardisation in Europe: Between Technological Choices and Neo-Protectionism." In Trends in Technological Innovation and the European Construction: The Emerging of Enduring Dynamics?, edited by Christophe Bouneau, David Burigana, and Antonio Varsori, 187-203. P.I.E Peter Lang.

Ramírez-Pérez, Sigfrido. 2016. "Multinational Corporations and European Integration: The Case of the Automobile Industry, 1959-1965.” Journal of European Integration History 22 (2): 329-354.

Schipper, Frank. 2008. Driving Europe: Building Europe on Roads in the Twentieth Century. Aksant.

SOU 1966:65. Luftföroreningar, buller och andra immissioner: lagförslag m.m. av Immissionssakkunniga. Ministry of Justice.

SOU 1979:34. Bilarna och luftföroreningarna, kartläggning av problemen: lägesrapport från bilavgaskommittén. Ministry of Agriculture.

SOU 1982:27. Svensk industri i utlandet: En analys av drivkrafter och effekter. Ministry of Industry.

SOU 1983: 27. Bilar och renare luft: Betänkande av bilavgaskommittén. Ministry of Agriculture.

SOU 1989:84. Ekonomiska styrmedel i miljöpolitiken: energi och trafik. Bilagedel. Ministry of Environment and Energy.

Streeck, Wolfgang, and Philippe C. Schmitter. 1999. "The Organization of Business Interests: Studying the Associative Action of Business in Advanced Industrial Societies”. MPIfG Discussion Paper, 99(1), 1-95.

Vinsel, Lee Jared. 2015. "Designing to the Test: Performance Standards and Technological Change in the U.S. Automobile after 1966." Technology and Culture 56 (4): 868-94.

Vogel, David. 1995. Trading Up: Consumer and Environmental Regulation in a Global Economy. Harvard University Press.

Vogel, David. 2012. The Politics of Precaution: Regulating Health, Safety, and Environmental Risks in Europe and the United States. Princeton University Press.

Walsh, Michael. 2011. “Automobile Emissions.” In The Reality of Precaution-Comparing Risk Regulation in the United States and Europe, edited by Jonathan B. Wiener, Michael D. Rogers, James K. Hammitt, and Peter H. Sand, 142-58. RFF Press.

Warlouzet, Laurent. 2020. "The Implementation of the Single Market Programme (1985-92): The examples of the Car Emission and Competition Policy." In Reshaping Europe: Towards a Political, Economic and Monetary Union, 1984-1989, edited by Michael Gehler and Wilfried Loth, 247-62. Nomos.

Wilkins, Mira. 1978. "Multinational Automobile Enterprises and Regulation: An Historical Overview." In Government, Technology and the Future of the Automobile, edited by Douglas H. Ginsburg and William J. Abernathy, 221-58. McGraw-Hill Book Company.

Wurzel, Rüdiger K. W. 2002. Environmental Policy-Making in Britain, Germany and the European Union. Manchester University Press. 


\section{Appendix}

Appendix 1. Indicative Comparative Stringency of a Selection of International Vehicle Emission Standards

\begin{tabular}{|c|c|c|c|c|c|c|}
\hline \multirow{2}{*}{$\begin{array}{l}\text { Regulation and } \\
\text { starting model } \\
\text { year* }\end{array}$} & \multicolumn{3}{|c|}{ Emission limits in $\mathrm{g} / \mathrm{km}$} & \multirow{2}{*}{$\begin{array}{l}\text { Driving } \\
\text { cycle }\end{array}$} & \multirow{2}{*}{$\begin{array}{l}\text { In-use } \\
\text { compliance } \\
\text { criteria }\end{array}$} & \multirow{2}{*}{$\begin{array}{l}\text { Examples of } \\
\text { emission control } \\
\text { technology used for } \\
\text { compliance }^{\star \star}\end{array}$} \\
\hline & $\mathrm{CO}$ & $\mathrm{HC}$ & $\mathrm{NO}_{x}$ & & & \\
\hline US $1983^{\star \star \star}$ & 2.11 & 0.25 & 0.62 & FTP-75 & Yes & $\begin{array}{l}\text { Three-way catalytic } \\
\text { converters }\end{array}$ \\
\hline Sweden 1971 & 45 & 2.2 & - & ECE 15 & No & Leaner air-fuel mix \\
\hline Sweden 1976 & 24.2 & 2.1 & 1.9 & FTP-72 & No & $\begin{array}{l}\text { EGR, retarded } \\
\text { ignition timing, } \\
\text { air injection }\end{array}$ \\
\hline $\begin{array}{l}\text { Regulation A } \\
101983\end{array}$ & 24.2 & 2.1 & 1.9 & FTP-72 & Yes & $\begin{array}{l}\text { Injection systems or } \\
\text { high-quality } \\
\text { carburetors }\end{array}$ \\
\hline $\begin{array}{l}\text { Regulation } \\
\quad 15-001972\end{array}$ & $24.7-54.3$ & $1.97-3.16$ & - & ECE 15 & No & Leaner air-fuel mix \\
\hline $\begin{array}{l}\text { Regulation } \\
\quad 15-031980\end{array}$ & $16-35.3$ & $1.48-2.37$ & $2.1-3.36$ & ECE 15 & No & $\begin{array}{l}\text { EGR, retarded } \\
\text { ignition timing, } \\
\text { air injection, } \\
\text { lower } \\
\text { compression }\end{array}$ \\
\hline $\begin{array}{l}\text { Regulation } \\
\text { 15-04 1984- } \\
86\end{array}$ & $14.3-27.1$ & $\begin{array}{r}4.69-6.91 \\
\lim \end{array}$ & mbined & ECE 15 & No & $\begin{array}{l}\text { Tight control of } \\
\text { air-fuel mix, } \\
\text { throttle } \\
\text { deceleration } \\
\text { systems }\end{array}$ \\
\hline $\begin{array}{l}\text { (Stockholm } \\
\text { Group) } \\
\text { MD-L1 } 1989\end{array}$ & 2.1 & 0.25 & 0.62 & FTP-75 & Varied & $\begin{array}{l}\text { Three-way catalytic } \\
\text { converters }\end{array}$ \\
\hline EEC 1992-93 & 2.72 & 0.97 (con & ed limit) & NEDC & Yes & $\begin{array}{l}\text { Three-way catalytic } \\
\text { converters }\end{array}$ \\
\hline
\end{tabular}

*Model year implementation for Regulation 15 is approximated owing to the voluntary implementation by countries of UNECE regulations.

${ }^{\star \star}$ Manufacturers often used combinations of different emission control systems and devices, depending on the strengths and weaknesses of various models in terms of emission test compliance.

$\star \star *$ Translated from $\mathrm{g} / \mathrm{mile}$ to $\mathrm{g} / \mathrm{km}$.

${ }^{\star \star \star *}$ Changes in the sampling and measuring procedure rendered the comparisons with earlier versions of Regulation 15 difficult.

Note: The emission limits in this table are reported as laid down in various regulations, which gives the false sense that they are immediately comparable. However, depending on variations in regulatory testing procedures (e.g., driving cycle, sampling equipment) and differences in compliance criteria and enforcement (e.g., durability requirements and spot-checks) the information only offers a very rough approximation. Moreover, Regulation 15 specified standards for nine different weight classes, where heavier cars had to meet less stringent requirements.

Cite this article: Näsman M, Pitteloud S (2022). The power and limits of expertise: Swiss-Swedish linking of vehicle emission standards in the 1970s and 1980s. Business and Politics 24, 241-260. https://doi.org/10.1017/bap.2022.3 